international environmental donor, can currently buy one US dollar of Costa Rica's debt for 25 cents from international banks that are eager to recoup losses. The Costa Rican Central Bank has agreed to pay 75 cents on the dollar for debt notes (in Costa Rican currency) - if-the money is put into conservation projects. Thus, the donor stands to get triple the value of his investment, and Costa Rica buys back some of its debt - at the same time keeping the money in the country.

Another 'debt for trees' agreement was recently reached in Bolivia, where the government agreed to establish three conservation areas totalling 3.7 million acres (approx. 1.7 million hectares) in exchange for notes of US $\$ 650,000$ face-value purchased by Conservation International, an organization based in Washington, DC.

The Central Bank of Costa Rica recently approved the proposed 'debt for conservation plan'. According to Dr Umana, one of the first projects to use the plan may be the proposed Guanacaste National Park. The Minister is currently working with WWF and Conservation International to raise one million US dollars, in order to purchase more than three million dollars' worth of debt and apply it to conservation in Guanacaste and other areas. This, however does not end the problems. 'The impact of the plan on overall debt is small', says Umana. 'This is not a way to pay the entire debt of the third world; instead, it is a way to help conservation, not only for Costa Rica, but for all the world.'

This method of relieving debt and aiding conservation was discussed at the 17th General Assembly of the International Union for Conservation of Nature and Natural Resources (IUCN), in San José, Costa Rica, 1-10 February 1988.* More than 500 natural resource managers from around the world attended to discuss conservation issues and develop new approaches-inter alia to such issues as this 'debt for conservation'.

\author{
H. WHELAN \\ IUCN General Assembly \\ Ministerio de Recursos Naturales \\ Energia y Minas, Apdo. 10104 \\ San José, Costa Rica.
}

* See the account in a forthcoming instalment of our Conferences \& Meetings section. - Ed.

\title{
An Opportunity for Poster Designers, Publishers, and Enthusiasts
}

Posters, or wall-charts, are used very frequently and widely nowadays to inform the general public about coming events, or to focus attention on various topics and issues. 'Ecoposters' are used so to disseminate conservational messages, and to inform and educate the public in awareness of Nature, wildlife, and environmental issues.

The fourth triennial exhibition of Ecoposters was opened to the public in Czechoslovakia during November 251987 to January $31 \mathrm{1988}$, in the town of Zilina, in northwestern Slovakia. During those several weeks visitors could admire the artistic spirit, creativeness, interpretation of conservation, and ecological messages, that were displayed. Interesting also was the selection of topics, and the quality of the print representing different aesthetic and other criteria.

There were more than 200 posters displayed, most of them being of Slovak or Czech origin. But the organizers received and exposed posters also from no fewer than 22 other countries, including USSR, Hungary, Bulgaria, Yugoslavia, Poland, German DR, FR of Germany, Denmark, Sweden, Finland, United Kingdom, France, Liechtenstein, Luxembourg, Austria, Japan, USA, Canada, Honduras, and Brazil.
The exhibition was accompanied by a competition for those designers, authors, or publishers, who were represented by posters at it. The committee of organizers judged all the posters that were received and exhibited and decided to recognize some selected ones by giving them awards.

The next, fifth, triennial exhibit of Ecoposters (or Ekoplagát, as they are called in Czechoslovakia), will be opened in November 1990. So, do not hesitate to participate there with samples of your own posters. Your intention to contribute to the next exhibition and secure space should be notified preliminarily to the undersigned, address given below. Then you can expect further instructions on a printed leaflet. And, if you would like to arrange a similar exhibit of those well-proved means of conservational and environmental education in your own country or region, you can ask at the same address for some Ecoposters from Czechoslovakia on loan or exchange.

\section{JÁN KLEINERT \\ Klokoćova 7 \\ CS-97401 Banská Bystrica Czechoslovakia.}

\section{'INSONA Conservation Award' for Environmental Achievement*}

Under its Patron-in-Chief HH Fatehsinghrao P. Gaekwad, the Indian Society of Naturalists (INSONA), with headquarters in Baroda, India, has instituted an Environmental Awareness Fund to honour a schoolchild every year for outstanding achievement in the field of environment. Nominations are accordingly invited (names and descriptions of their work) for the 'INSONA Conservation Award' of 1988 for environmental achievement, to reach the General Secretary at Baroda not later than 5th June 1988. No child should nominate himself/herself, but his/her institution must do so on his/her behalf.
The award being established to extend INSONA's tributes to endeavours/successes achieved in the service of the global environmental cause, the recipient each year will be presented with Rupees one thousand in cash and a memento. The recipients shall ultimately become an integral part of INSONA's cause for human well-being through

* Although this award was evidently intended for the school children of India, it seemed such an excellent idea that we are now happy to be able to announce that it is to be available henceforth to schoolchildren of all nations. $-\mathrm{Ed}$. 